\title{
Beyond post-Christendom discipleship of the Evangelical Church in the United Kingdom: A study of the Gospel of Matthew in the transformissional and holistic perspective
}

\begin{tabular}{|c|c|}
\hline \multicolumn{2}{|c|}{$\begin{array}{l}\text { Authors: } \\
\text { Desmond Henry }{ }^{1} \\
\text { Max F. Swart }\end{array}$} \\
\hline \multicolumn{2}{|c|}{$\begin{array}{l}\text { Affiliations: } \\
\text { 'Department of Missiology, } \\
\text { Faculty of Theology, } \\
\text { North-West University, } \\
\text { Potchefstroom, South Africa }\end{array}$} \\
\hline \multicolumn{2}{|c|}{$\begin{array}{l}\text { Corresponding author: } \\
\text { Desmond Henry, } \\
\text { desandlara@gmail.com }\end{array}$} \\
\hline \multicolumn{2}{|c|}{$\begin{array}{l}\text { Dates: } \\
\text { Received: } 24 \text { Feb. } 2021 \\
\text { Accepted: } 04 \text { May } 2021 \\
\text { Published: } 14 \text { June } 2021\end{array}$} \\
\hline \multicolumn{2}{|c|}{$\begin{array}{l}\text { How to cite this article: } \\
\text { Henry, D. \& Swart, M.F., } \\
\text { 2021, 'Beyond post- } \\
\text { Christendom discipleship of } \\
\text { the Evangelical Church in the } \\
\text { United Kingdom: A study of } \\
\text { the Gospel of Matthew in } \\
\text { the transformissional and } \\
\text { holistic perspective', Verbum } \\
\text { et Ecclesia } 42(1), \text { a2229. } \\
\text { https://doi.org/10.4102/ } \\
\text { ve.v42i1.2229 }\end{array}$} \\
\hline \multicolumn{2}{|c|}{$\begin{array}{l}\text { Copyright: } \\
\text { ( } 2021 \text {. The Authors. } \\
\text { Licensee: AOSIS. This work } \\
\text { is licensed under the } \\
\text { Creative Commons } \\
\text { Attribution License. }\end{array}$} \\
\hline \multicolumn{2}{|l|}{ Read online: } \\
\hline 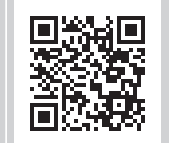 & $\begin{array}{l}\text { Scan this QR } \\
\text { code with your } \\
\text { smart phone or } \\
\text { mobile device } \\
\text { to read online. }\end{array}$ \\
\hline
\end{tabular}

Discipleship has been, and continues to be, integral to the church's strategy to simultaneously contribute towards the spiritual formation of its members and also fulfilling its mission. From the very outset of the church, Jesus demonstrated the centrality of discipleship through what he taught and practiced. However, as the United Kingdom moved into the post-Christendom era, the Evangelical Church has grappled with being effective in discipleship. Through a study in the Gospel of Matthew in the transformissional and holistic perspective, the article seeks to aid this vital part of the church's strategy by suggesting a paradigm shift and reprioritisation of the discipleship emphasis.

Intradisciplinary and/or interdisciplinary implications: The article will suggest a paradigm shift to the traditional discipleship discourse of post-Christendom era evangelical churches in the United Kingdom. The research will review Scripture, practical theology and interdisciplinary fields such as the influence of Christianity on health and family to establish a more holistically focussed and transformissional discipleship perspective.

Keywords: discipleship; evangelical; holistic; mission; transformissional; church.

\section{Introduction}

Throughout his earthly ministry, Jesus demonstrated the prominence of discipleship for the success of his ongoing mission. The closing pericope of Matthew's Gospel brings things to a crescendo when Jesus, in his final instructions prior to ascension, commissioned his followers into an ongoing discipleship mandate. Thousands of years later, evangelical churches are still striving to be obedient to this commission. Yet, the post-Christendom era Evangelical Church in the United Kingdom is grappling with applying and implementing discipleship and mission (Murray 2018:3). Authors, like Willard (2014:3), conclude that the church, in the Western world, has even stopped making discipleship conditional to being Christian. Recent studies, like those by the Evangelical Alliance and Elim, identify the lack of a holistic and missional focus in discipleship (cf. EA UK 2014, 2020; Elim 2020). These studies indicate that the discipleship approaches, currently used as the primary discipleship tools in evangelical churches, are fragmented and develop non-missional and atomistic disciples who are ill equipped to fulfil the great commission. Studying discipleship in the Gospel of Matthew reveals that Jesus' discipleship was focussed on transforming individuals for mission, which is described by the term 'transformissional' that was first coined by Ogne and Roehl (2019:3). Furthermore, Jesus' discipleship took place within a worldview where the constitutional nature of an individual was understood as a unitarian whole, which informs the holistic emphasis of his discipleship. This article introduces a paradigm shift when thinking about discipleship, by arguing that the post-Christendom era Evangelical Church in the United Kingdom can benefit from learning about transformissional and holistic discipleship in the Gospel of Matthew.

\section{The Gospel of Matthew}

Matthew is considered to be one of the most important books in world history, and it is believed to have been quoted more than any other book (Clarke 2003:xxi). The author of Matthew is deemed to be equal to the apostles John and Paul in the creation of Christian identity. Furthermore, because of its comprehensive scope, Matthew can simultaneously be considered 'the church's gospel' and 'the Jewish gospel' (Clarke 2003:xx-xxi; eds. Zangenberg \& Van de Sandt 2008:1 \& 4). One of the reasons for selecting the Gospel of Matthew as the primary scriptural source for this 
study is that it spans the width of the Judeo-Christian perspective.

Although the authorship of the Gospel has been attributed to the Apostle Matthew (the tax collector in Mt 9:9 or 'Levi' in Mk 2:14), the author is unknown. Matthew was written from a compilation of sources as opposed to being an eyewitness account. Therefore, the tradition crediting the authorship of the Gospel to the Apostle is contradicted by the Gospel itself. The insight into Judaism contained in the Gospel suggests that the author was a converted Pharisee or rabbi (Allen 2010:1xxix-lxxx; Clarke 2003:xxi-xxii). However, the most likely reason for ascribing the Gospel to the Apostle Matthew is because of a significant amount of its content containing the apostle's Logia or sayings of Christ. This is in agreement with other groups, like the Jewish Christian Nazarenes, who also ascribed the authorship of the Gospel to the Apostle Matthew based on similar grounds (Allen 2010:1xxxiii).

It is believed that Matthew's Gospel was addressing a group of second-generation Christians who still considered themselves within the orbit of Judaism, making them a sect within the Jewish community (Sim 1998:3-6). Most scholars are in consensus that the Gospel was written after the first Jewish revolt, in the rough period between $\mathrm{AD} 70$ and $\mathrm{AD}$ 100. The timeframe is largely determined by Matthew 22:7, mentioning the destruction of a city, which is understood as a retrospective reference to the destruction of Jerusalem in AD 70 (cf. Allen 2010:lxxxiv; Clarke 2003:xxii; Sim 1998:31, 34 \& 39; eds. Zangenberg \& Van de Sandt 2008:2). The destruction of Jerusalem resulted in many Jews being dispersed from their homeland, and the group of Christian Jews that Matthew's Gospel is addressing, re-gathered in Antioch, the capital of Syria. Seeing that they were still considering themselves Jewish, they were in contact with other sects within formative Judaism. Furthermore, as a result of them settling in a Gentile city, they were also in contact with Gentile Christians. It is this tension and conflict between sects within Judaism and other faith groups that created the need for a clear Jewish Christian identity, which the author of the Gospel was attempting to address (Clarke 2003:xxii; Sim 1998:62 \& 300).

This community of Christian Jews in Antioch was struggling with both an internal identity crisis and an external implementation of the missional teaching of Jesus. The teaching of Jesus in the Gospel is clearly demonstrating a universalist goal to reach all nations, yet the community was reluctant to admit Gentiles (Allen 2010:lxxvii). The tension is described by Clarke (2003:xxiv), stating that the author of Matthew 'finds himself at a divide of worlds, between a Judaism that is in transition and a Christianity that is still in its beginnings'. This leads to the author looking back to the Old Testament and Israel for validation and simultaneously forward to the mission of Christ to reach all nations. This balance between the tension of looking back to the Old Testament and forward to the mission of reaching all nations delivers a unique discipleship perspective in the Gospel. In this tension, the Hebraic Old Testament view of man, as a unitary being, provides an insight into Jesus' ontological worldview, addressing the holistic element in this study (cf. Beck 2003:25; Berkhof 1958:208; Erickson 1998:544; Grudem 1994:473; Jee 2017:61). Also, the missional discourse, and eventual conclusion commissioning Christ followers to make disciples of all nations, highlights the need for the disciples to be transformed by Jesus in order to join his mission.

The post-Christendom era Evangelical Church in the United Kingdom currently also finds itself at a transitional point of having to redefine itself in a culture where the predominant Christian worldview is vanishing, whilst simultaneously grappling with discipleship in order to fulfil the great commission. This tension is not unlike what was experienced by the church in Antioch, having to look back to Scripture for validation and forward to the nations for mission.

\section{Holistic discipleship}

Philosophers, scientists, psychologists and theologians have all wrestled with comprehending the constitutional nature of humanity. This quest to understand human ontology is ancient and can be traced back to the early age of Greek culture (Cooper 2013:482; Frede \& Reis 2009:1). It is outside the scope of this article to discuss the various ontological views of humanity in great detail. However, as a broad definition, there are two philosophical tracks of thinking about anthropology.

The first track, and the most significant to this article, is the Hebraic understanding of the make-up of humanity. The Gospel of Matthew was deeply rooted in the Hebrew culture and thought, which informed the Judeo-Christian understanding of the original audience of the Gospel. Furthermore, all the New Testament authors were Jews who shared a common understanding of humanity. Thus, when Jesus, Paul and the other New Testament authors used terms like 'spirit', 'soul' or 'body', they were writing from the Hebraic view of man as a holistic entity. These terms were not used to identify a particular element of the human constitution, but rather the whole of the person (Erickson 1998:544; Grudem 1994:475).

The second track is different to the Hebraic view, understanding humans as unitarian beings, and offers a sectarian view of the material or immaterial constitutional elements of humanity. This worldview was informed by the Greco-Roman world, which in turn was heavily influenced by Greek philosophy. The Greek philosophical ideas emerged from a pagan system that had no inkling of the Hebraic view of humanity (Beck 2003:27). Erickson (1998:544) concurs with Beck and emphasises that the Hebrew and Greek philosophical views were mutually unaware of each other. The lack of orthodoxy in Greek religion paved the way for various contradictory views, all attempting to define the constitutional nature of humans to arise. Most of the views were either monist or dualist in orientation. However, some conservative evangelical and Protestant Christians also hold 
to trichotomism, which is more in alignment with pagan metaphysics than sound scriptural exposition (cf. Erickson 1998:538-539; Frede \& Reis 2009:1-2; Grudem 1994:472). Seeing that the 'nature and career of the human soul' is of significance to Christianity, the early church fathers grappled with both the pagan philosophy and scripture to express their own views. It was from this era of church history onwards that the Greek philosophical sectarian views infiltrated Christian understanding and displaced the unitarian Hebraic understanding (Frede \& Reis 2009:447).

The view which underpins the foundational ontological understanding referred to in this article is holism. Although holism predominantly identifies with a range of theories that are dualistic in orientation, it pays closer attention to the psychophysical nature of humans leading to a more holistic understanding (Cooper 2013:483; Cortez 2008:157-158). Grudem argued that the unitary view of humanity in Scripture, particularly the Old Testament, does not have a concept of 'the existence of the soul apart from the body' (Grudem 1994:475). Beck (2003:26) agreed with this view stating that the Old Testament doesn't have a 'full-blown' dualism or monism. Rather, it more accurately portrays humans with a holistic emphasis containing a dualistic implication. Holism identifies a human as one functional whole. The whole may consist of distinct entities, but these can't operate independently within the whole, which is often argued by sectarian views of ontology (Cooper 2000:45).

Scholars argue that this anthropological understanding of the constitutional nature of humanity is in closer alignment with Scripture than the dualistic, monistic and trichotomistic views that are rooted in pagan Greek philosophy. This expression of a unified human nature is first expressed in Genesis 2:7, where God breathes life into Adam. The account indicates the complex unified nature of man, where the two elements of human nature are brought together, and this unified view of man continues throughout Scripture. Thus, every act of a human is an act of the whole person, rather than an individual element of the person (cf. Beck 2003:26; Berkhof 1958:208; Grudem 1994:473).

There are several implications (Beck 2003:26; Cortez 2008:181 \& 183; Grudem 1994:482) of the holistic understanding of human nature to consider, pertaining to discipleship offered by Erickson ${ }^{1}$ (1998:557):

1. Humans are to be treated as unities. Their spiritual condition cannot be dealt with independently of their physical and psychological condition, and vice versa. The Christian who desires to be spiritually healthy will give attention to such matters as diet, rest and exercise. Any attempt to deal with people's spiritual condition apart from their physical condition and mental and emotional state will be only partially successful, as will any attempt to deal with human emotions apart from people's relationship with God.

1.This is a near verbatim quotation of Erickson. The full extract has been edited to shorten it in order to highlight the most relevant implications.
2. A human is a complex being, whose nature is not reducible to a single principle.

3. The different aspects of human nature are all to be attended to and respected. There is to be no depreciation of the body, emotions or intellect. The gospel is an appeal to the whole person. It is significant that Jesus in his incarnation became fully human, for he came to redeem the whole of what we are.

4. Religious development or maturity does not consist in subjugating one part of human nature to another. No part of the human makeup is evil per se. Total depravity means that sin infects all of what a human is. God is at work renewing the whole of what we are.

These implications have direct resonance to the postChristendom era Evangelical Church in the United Kingdom. As will be demonstrated in the next section of the article, discipleship in the considered context often only deals with the intellect or spirit of the individual and not the holistic unit. Thus, inevitably the Gospel isn't an appeal to the whole person, but instead is aimed at appealing to the spirit or intellect of a person. Furthermore, often the renewal work of God is understood in the context of practicing spiritual disciplines, subjugating the body to the spirit, and the holistic renewal of the whole person is neglected.

\section{Holistic discipleship in the Gospel of Matthew}

Although the Gospel of Matthew is rooted in the unitary Hebraic understanding of ontology, much of that understanding is implicit. However, Matthew 22:34-40 contains direct implications for holistic discipleship. The study, of the holistic understanding in Matthew, will commence with this passage followed by two summaries of further texts that implicitly reveal the holistic understanding in Matthew.

\section{Matthew 22:34-40}

In this pericope, Jesus is questioned by a Pharisaic lawyer about a technicality in Jewish law in an attempt to ensnare him. The encounter will be considered in three focus areas below, namely, the confrontation, the answer and the implications.

\section{The confrontation}

This pericope is the third and final of a series of confrontations between Jesus and the Jewish religious leaders. Although the confrontation can be described as straightforward and the least controversial of the three, it leads to multiple very significant revelations (Hagner 1995:644; Turner 2008:534; Osborne 2010:ch.96, par.1). The pericope contains several edits from the same account in the Gospel of Mark, which is believed to have been one of the major sources for the Gospel of Matthew. These edits were incorporated to emphasise the increased tension between Jesus and the Pharisees, because it was of particular relevance to the original audience, 
who were living under increasing tension with the Pharisees in Antioch. The question itself was a hostile test to determine whether Jesus belonged to a radical fringe group within mainstream Judaism (Hagner 1995:644-645; Osborne 2010:ch.96, par.3).

There was an ongoing debate within Judaism about the greatest commandment (Hagner 1995:646; Keener 2009:530). However, in a culture of honour and shame, the question wasn't rooted in a desire for an answer; it was a direct public challenge to Jesus' honour. Whoever emerged victorious from this challenge would acquire honour and as a result carry more societal acknowledgement (Malina 2001:30-33). The confrontation is also bigger than a clash of two individuals. The Pharisee and Jesus were both considered a 'holy person' (Robbins 1996:121), each representing an ideological understanding of Judaism, the Torah and relating to God. The victor of the confrontation would not only gain honour, but also establish the validity of their ideology. There was significant reputational, ideological and theological authority at stake for both Jesus and the Pharisee. Saldarini (1994:87-88) argues that understanding social conflict theory will clarify the intentions of the author of Matthew for portraying the confrontation in the way he did. Conflict is vital to creating social identity and seeing that the audience of Matthew were engaged in an inner Jewish debate with formative Judaism, and Jesus' response to the confrontation renewed their sense of group identity and purpose.

\section{The answer}

This pericope contains several references to teacher, lawyer and a repetition of the word 'commandment' three times. This serves the purpose of illustrating the importance of the Torah and Jewish legal system to Jesus, the author and also the original audience (Davies \& Allison 2004:381; Turner 2008:535). Furthermore, although the question posed to Jesus was a relevant question, debated within Judaism, his answer presents an alternative interpretation of the law (Hagner 1995;646; Keener 2009:530; Sim 1998:139; Turner 2008:534).

Jesus, in his answer, uses the techniques of 'recontextualisation' and 'reference' to base his answer on two Old Testament passages and cultural traditions (Robbins 1996:40, 48 \& 58). He is using passages that were central to Judaism to craft his answer (Turner 2008:536). First, in his description of the greatest commandment, he refers to Deuteronomy 6:5. This passage contains the Shema, which was one of the best-known texts of Judaism. It was a Jewish tradition to recite the Shema twice daily, and it is understood to sum up the Jewish faith and practice. This first commandment clearly describes the holistic nature of discipleship. The three faculties described represent the entire person, demanding total love for God with every fibre of one's being (cf. Hagner 1995:647; Keener 2009:530; Osborne 2010:ch. 96, par. 9-10; Turner 2008:536). This commandment not only depends on the Shema for authentication but can also be recognised as an elaboration of and fulfilment of the first table of the Decalogue, containing the commands regarding loving and worshipping God (Hagner 1995:647; Osborne 2010:ch.96, par.13).

The second commandment references Leviticus 19:18, and in the process fulfils the second table of the Decalogue, containing the 'ethical commands on relating to others' (Osborne 2010:ch.96, par.13). Keener (2009:531) argued that Jesus used the rabbinic interpretive principle, known as 'gezerah shewah', by linking two commandments on the basis of the common opening words, which in this case is 'You shall love'. This, according to Osborne (2010:ch.96, par.13), is 'fulfilment language' in that these two Old Testament passages referenced 'complete and bring into fulfilment all of Scripture'. Jesus' second commandment serves as a reminder that holistic discipleship flows into mission, by loving others. Followers of Jesus can't claim to love God, if they don't love others (Osborne 2010:ch.96, par. 14).

The two love commandments, offered by Jesus, are essential in establishing holistic discipleship. They are interdependent, the first demonstrating the vertical relationship between the disciple and God, and the second indicating the horizontal relationship a disciple has with others. One important observation is that neither of the commandments refers to love as an emotion. Unlike an emotion, the love Jesus referred to can be commanded. Firstly, it is a way of life of devotion to God, understood as reverence, commitment and obedience with every fibre of our human existence. Secondly, love for others acts selflessly for the good of the other individual. In the case of Matthew's argument, the only good for others is to enter into a discipleship relationship with God, thus this love becoming missional in nature (cf. Davies \& Allison 2004:381; Hagner 1995:648; Keener 2009:530-531; Osborne 2010:ch.96, par.18; Turner 2008:537).

Jesus' answer silenced the Pharisee, indicating that the lawyer could not find fault with it. Not only was this answer acceptable but it also gained the public honour that the Pharisee was determined to detract from him. The author uses the narrational silence from the Pharisee to leave the words of Jesus 'ringing in the readers ears' (Anderson 1994:125; Turner 2008:537). Love is presented by Jesus as the central principle of interpreting the Torah. Through this, Jesus offered an alternative exegesis of two primary Jewish texts to lay the foundation of holistic discipleship that leads to mission (Sim 1998:127-128).

\section{The implications}

Jesus' answer not only silenced his examiner but also introduced the foundations for the ethical teaching that all New Testament Christianity was established on (cf. Davies \& Allison 2004:382; Hagner 1995:647; Osborne 2010:ch.96, par.12; Turner 2008:534). The implications of Jesus' answer reach further than the original audience of the Gospel - all Christians, including the post-Christendom era Evangelical Church in the United Kingdom. 
Two principles were established by Jesus. Firstly, true discipleship requires holistic love for God. This love response demands every fibre of an individual's being to be devoted to God in reverence and obedience. Secondly, loving God naturally flows outwards towards loving others. This is not an emotional love, but rather sacrificially seeking the benefit of others. In the context of Matthew, the best interest for any person is a closer relationship with God through Jesus. Therefore, loving others isn't simply social or practical, but ultimately missional. These two love responses are interlinked and interdependent and can't function separately from each other. Jesus' ethics can be summarised as holistic love for God and missional love for your neighbour.

\section{Matthew 1:18-25}

The incarnation of Jesus is relevant to and supportive of the holistic ontological understanding, seeing that understanding human nature begins with a 'consideration of God's self-revelation in Jesus and its import on anthropology' (Cortez 2008:21-22). Steenberg (2009:1-2) agreed with the central relevance of Christ on understanding anthropology. According to Steenberg, the incarnation of Jesus is the central 'theological vision' affecting the reality of the entire human race. Furthermore, Christianity is in equal measure theology and anthropology, with both subjects only fully understood in the person of Jesus, commencing with his incarnation.

It is argued by Erickson (1998:557) that the incarnation is significant because 'Jesus in his incarnation became fully human'. The humanity of the incarnate Christ is evident in that he experienced emotions, like compassion (Mt 14:14) was tempted (Mt 4:1-11) and became tired (Mt 8:27). Furthermore, his teaching on the soul, spirit and body is in alignment with the unitarian Hebraic view of humanity. He doesn't divide human ontology into separate faculties, but in the instances when he references individual terms it is from the Hebraic foundation where reference to these terms imply the entire person (Grudem 1994:475). Through his incarnation, Jesus became fully man, experiencing everything common to man, and his teaching supports the holistic understanding of ontology.

\section{Matthew 10:28}

At a cursory glance, this verse appears to endorse substance dualism based in Greek metaphysics. However, the Gospel of Matthew was rooted in the Jewish unitary understanding of anthropology, and this becomes apparent when the passage is scrutinised (Berkouwer 1962:200). Although the immediate context is the disciples overcoming fear of persecution, Jesus does reference the body and soul independently. Osborne (2010) observed that:

Jesus is not drawing an absolute distinction between the two parts of the human being, body and soul, as if we are a dualistic being rather than a whole person. (ch.43, par. 15-16)
Erickson (1998:554) agrees by stating that although 'the body and soul are sometimes contrasted', they are not always distinguished. This is because of the fact that Scripture pictures humans 'for the most part as a unitary being'. Scholars are in consensus that although two parts of the human constitution are mentioned, soul doesn't simply entail an entity of human make-up, but rather the whole person (cf. Grudem 1994:475; Hagner 1993:286; Keener 2009:326; Osborne 2010:ch.43, par.15-16). Thus, it could be argued that body and soul are not referred to as two detachable elements, but instead two perspectives of analysis. Pedersen (1926:171) illustrated this by arguing that 'the body is the soul in its outward form'.

Thus, it is evident that the Gospel of Matthew both implicitly, from a Hebraic understanding, and explicitly in the teaching of Jesus argues for the holistic nature of man. Consequently, discipleship should be holistic in orientation.

\section{Transformissional discipleship}

The term 'transformissional' was coined by Ogne and Roehl (2019:3) and refers to individuals who are being transformed, through their relationship with Jesus, in order to join his mission. This principle is evident in the discipleship practice and teaching of Jesus, as will be highlighted by the overview of Matthew 4:18-22 and summaries of two further passages in Matthew.

\section{Matthew 4:18-22}

The pericope takes place at the beginning of the public ministry of Jesus and recounts the calling of the first four disciples. This call account, in particular by containing a near verbatim double story, emphasises that this is a prototype model of the typical nature of true discipleship (Anderson 1994:131-132; Hagner 1993:76 \& 78; Turner 2008:137). Thus, it identifies important principles applicable to all future disciples.

\section{The setting}

The two sets of brothers can be identified as commercial fishermen, by the type of circular net described (cf. Davies \& Allison 2004:58; Hagner 1993:76; Osborne 2010:ch.9, par.8; Turner 2008:136). In their Galilean peasant culture, fishing was an economically mobile profession, second to agriculture (Keener 2009:151; Osborne 2010:ch.9, par. 8). In this society, there was often a clan-based system of reciprocity, where family goods and services were freely shared (Robbins 1996:83). This reciprocity is evident in the reference to two sets of brothers (4:18 \& 4:21), and the second set working with their father (4:21-22), in what is perceived as their family business.

\section{The call}

Although there are several cultural similarities with both Greek and Hebrew teachers, Keener (2009:150) argues that Jesus, by taking the initiative in the calling process, is 
committing a 'serious breach of custom' (cf. Carter 1997:66; Droge 1983:251; Hagner 1993:76; Talbert 2010:74). This description of Jesus taking the initiative to call the disciples positions him as the creative force in discipleship (Osborne 2010:ch.9, par. 2). Furthermore, Nolland (2005:179) observed the abrupt nature of the call by stating, 'the abruptness of the call is matched by the immediacy of the following'. Both of these amplify the significance of following Jesus. Although this call is often likened to the calling of Elisha in 1 Kings 19:19-21, Davies and Allison (2004:57) comments that Jesus required more from his disciples than Elijah did from Elisha. This, according to Keener (2009:149), is because of Jesus being a radical teacher requiring radical disciples.

Responding to the call of Jesus came at a cost, economically they left their trade as fishermen to follow Jesus, and socially they had to leave their families. There was no greater social responsibility than to care for parents and leaving their family businesses to follow Jesus required a radical reorientation of priorities (cf. Hagner 1993:76 \& 78; Keener 2009:151-153). Carter (1997:73) describes this reorientation of priorities as an 'ambivalent relationship with society, between detachment and participation, in allegiance to Jesus'. Matthew refers to the familial relationship, like 'fatherson and brother-to-brother', to portray the concept of kinship. Furthermore, there is a 'master-disciple' relationship that in the case of Jesus requires a commitment beyond familial ties in the form of fictive kinship (cf. Malina 1996:146; Saldarini 1994:90-91). Thus, Jesus' followers become a new community with ties that are stronger than family bonds.

\section{The implications}

Jesus calling the disciples required them to remove themselves from normal social and economic ties and enter into a persistent commitment to follow him. This following enabled them to be transformed by him, and the primary purpose for this transformation is the recruitment of more members (Saldarini 1994:99). Carter (1997:67) agrees by describing that when the disciples responded to the call of Jesus, they detached themselves from their 'nets $(4: 20,22)$, from their boat, their father, their occupation, their possessions and their family', so that they can participate in the saving will of God.

\section{Matthew 5:13-16}

This pericope speaks into the transformed life required of disciples. The beautitudes, which are contained in the preceding context to this pericope, outlines the ethics of living as disciples in God's Kingdom (Hagner 1993:97). Being a disciple is more than good deeds, but rather about living out a transformed character. Jesus in his teaching explained what a transformed life looks like, and if disciples do not live this lifestyle, they are 'worth about as much as tasteless salt and invisible light' (Keener 2009:172). In Matthew's Gospel, discipleship started with the call described in chapter 4; the call explained how Jesus transforms disciples when they follow him. Now, he is teaching them the ethics and actions of the transformed life. Osborne (2020:ch.12, par.2) commented that disciples are Kingdom people who 'must be visible to change the nature of the world around them'. Thus, disciples are transformed to join the mission of Jesus.

\section{Matthew 28:16-20}

Although Matthew contains other commissioning and 'making disciples' accounts (Mt 10; Mt 13:52; Mt 27:57), this pericope brings the Gospel's narrative to a climax (Hagner 1995:881; Osborne 2010:ch.122, par.29). The commission is not purely a command to preach the Gospel, but rather emphasises the importance of nurturing the 'experience of discipleship'. The fulfilling of the commission is only made possible by the authority of Jesus (v. 18) and his presence (v. 20) (Hagner 1995:886-887; Osborne 2010:ch. 122, par. 32).

Therefore, it can be summarised that being a disciple is a lifelong commitment to Jesus, leading to being transformed and in turn being used by him to bring others into this transformational life. Davies and Allison (2004:548-549) espouse that the pericope satisfactorily 'completes the Gospel'. It does so by summarising Matthean theology through resonating with themes contained throughout the Gospel. Furthermore, they comment that the climax and crown of Matthew's Gospel is profoundly apt in that it invites the reader to enter the story; $28: 16-20$ is an open-ended ending'. The disciples continue following Jesus, who remains ever present, and as a result, they are continually being transformed and fulfilling his mission.

\section{Summary of transformissional and holistic discipleship in Matthew}

This study in Matthew, although not exhaustive, identifies that Jesus' discipleship was not programmatic, intellectual or purely spiritual in orientation. Jesus' discipleship was holistic in that it focussed on the entire person being devoted to God. Through following Jesus, an individual is transformed by his presence, example and teaching. Furthermore, the purpose of discipleship is not exclusively transformation of individuals, but transforming them in order to be able to join his mission. Disciples who do not live out this transformed reality, in a way that impacts the world around them, are considered worthless. Thus, Jesus' discipleship is holistic and transformissional in nature.

\section{Discipleship of the post- Christendom era Evangelical Church in the United Kingdom}

\section{Post-Christendom}

The term 'Christendom' can loosely be used to refer to the extent of Christian belief amongst a population. However, for the purpose of this article, Christendom will be referred to within the framework presented by Kaye (2018: intro., par. 8). According to this view, the English Christendom was a micro-Christendom where the 'political unit' professed to 
be a Christian polity. The English Christendom was distinctive to other Christendoms, by having a shared mission between bishop and king combined in one role. The 'royal power' and 'church power' united under one figurehead, to order and evangelise the subjects of the monarch (Kaye 2018:ch.10, par. 18 \& 22).

Post-Christendom should therefore not be confused with post-Christian. Murray (2018:ch. 1, par. 16-26) highlights that 'the demise of Christendom does mean the Christian story is becoming unfamiliar'. However, Christianity is still relevant, making a significant contribution to society and, in some contexts, showing a growth trend. Furthermore, there are questions as to whether the European Christendom was Christian or simply a religious 'veneer' (Murray 2018:ch.1, par.35). The end of Christendom marks the end of institutionalised and cultural Christianity, as well as a Christian worldview in society, but not the validity and relevance of Christ followers.

Although it presents a new cultural context, if the church can adapt missionally, there are opportunities to tell and live out the Christian story in a society where it is largely unknown (Murray 2018:ch.1, par.34). It is suggested that the demise of Christendom offers the opportunity to restore the 'distinctiveness of the early Christian character'. Therefore, Kaye (2018:ch.10, par.53-55) refers to Kreider (2016) appealing to early Christianity in order to point a 'new way' to the post-Christendom society. In summary, the Evangelical Church within the United Kingdom finds itself in this post-Christendom era, facing both the challenge and opportunity it offers.

\section{United Kingdom-specific discipleship research}

In recent years, various groups have published the results of studies on evangelism and discipleship within the United Kingdom's evangelical context. All the reports identify many areas where the church is excelling and simultaneously provide transparent and honest insight into areas that are struggling. Following is a summary of some of the findings of this research, specifically relating to the topic of this article, in order to shed light on the condition of discipleship practice in the post-Christendom era Evangelical Church in the United Kingdom.

\section{Research by the Evangelical Alliance in the United Kingdom}

In the spring of 2014, the Evangelical Alliance released a report focussed on discipleship within the United Kingdom's evangelical context; this was part of an ongoing research project which started in 2011. When respondents were asked how successfully they were being discipled, there was a positive response that $67 \%$ of people felt that early in their conversion journey, they were helped to understand the basics of the Christian faith; $57 \%$ responded that their faith increased; and $49 \%$ felt enthused to read their Bible. However, less than half felt equipped in their general lifestyles. Only $46 \%$ of people felt the discipleship they received helped them develop a Christian lifestyle, and $45 \%$ felt equipped to live the Christian life in their relationships. Worryingly, 38\% of people felt inspired to live like Christ in work and public life, $32 \%$ of people felt encouraged to use their talents in the wider community, 31\% were helped to shape good habits in their prayer life and only $26 \%$ of respondents felt equipped to witness and share their faith (EA UK 2014:9). Furthermore, only $40 \%$ of people felt their church did well at discipling new believers (EA UK 2014:22).

Other trends of interest include that $70 \%$ of respondents felt attending church or large Christian gathering was helpful in their walk with God, and church leaders were by far the largest source of inspiration with $60 \%$ of respondents being impacted by a church leader (EA UK 2014:15 \& 21). The report seems to highlight that although $65 \%$ of respondents experienced 'formal teaching or discipling', most of this was programmatic (EA UK 2014:8). It can also be concluded from the topics of focus like prayer, Bible study and devotional life that churches predominantly focus on head knowledge and personal devotion rather than lifestyle and faith sharing.

More recently, as a result of the coronavirus pandemic, the Evangelical Alliance commissioned further research directly relating to the pandemic. The research was entitled Changing Church and focussed on various aspects including discipleship, evangelism and community transformation. One interesting aspect of this report is the direct presentation of answers from individuals compared to church leaders with regard to some topics. For example, $67 \%$ of individuals felt church services were beneficial to their discipleship, but by contrast $86 \%$ of church leaders felt church services were beneficial in the discipleship of their congregations. More than half of church leaders identified that more resources on evangelism and discipleship would be helpful (EA UK 2020:3-4). The report highlighted that $34 \%$ of individuals felt their church was 'not at all' helping them with evangelism, a further combined $56 \%$ felt that their church was helping with evangelism somewhat or occasionally (EA UK 2020:5). The report identified that despite the lack of evangelism focus in church, people still shared their faith and invited friends to evangelism initiatives, but the biggest obstacle to evangelism was a lack of Christian friends (EA UK 2020:5-6).

There are many beneficial and encouraging things happening through the Evangelical Church in the United Kingdom. However, the findings from these reports identify that discipleship in this context is predominantly programmatic, church service based, centred on personalities of leaders, focussed on the head and devotional disciplines. All of these things are valid, but not at the expense of not discipling believers in their lifestyles, relationships and how to share their faith. Furthermore, there is a need for a greater focus on and resources to help church leaders with discipling their congregations and evangelism.

\section{Research by Elim}

In 2020, Elim - an evangelical denomination within the United Kingdom - published findings from research they 
conducted on discipleship within their context. Although their research focussed on a relatively small sample, they only surveyed 16 of their 550 churches, it can be anticipated that the responses are a fair representation of the bigger picture. It is encouraging that Elim expresses the desire to 'transform society and individuals through the actions and prayers of fully mature, fully committed, and fully confident disciples of Jesus'. Furthermore, there is an acknowledgement that there isn't enough of an understanding of the good practices that help disciples to be formed (Elim 2020:2 \& 4).

The research delivered several relevant findings including that nearly all the senior leaders of the surveyed churches expressed their church's limitations in making disciples. Also, the church leaders were aware that they needed practices in their church to constantly reinforce discipleship. Finally, the centrality of Sunday services was emphasised. However, the end of the report stressed that Sunday's are not primarily about discipleship (Elim 2020:5 \& 16). In light of the centrality of gathered church services, it is interesting to note that respondents said their church was helping them 'a fair bit' to share their faith and with issues faced by Christians in everyday life and 'a little' in using their spiritual gifts in everyday life and values what they do beyond churchcentred activities. However, people felt their church focussed 'a lot' on how the Gospel is good news, inspirational stories of God at work and prayer for everyday life. Although church services are central and emphasis on living as Christians in everyday life is limited, people reported spending $48 \%$ of their time in the workplace with nonChristians (Elim 2020:7-8).

Finally, the research identified an unexpected link between purpose and spiritual growth. People who understood their purpose were also the ones who are more confident in their faith, more likely to engage with spiritual disciplines, know how to be a disciple in the daily context and are supported and accountable (Elim 2020:10-14). The question begs to be asked, how would spiritual growth be affected if people understood their purpose to be disciples who are being holistically transformed in order to join Jesus' mission of making more disciples?

\section{Comparison with the transformissional and holistic perspective in Matthew}

There appears to be a stark contrast between the focus of Jesus' discipleship revealed in the study of Matthew when compared to the focus of post-Christendom era evangelical churches in the United Kingdom. Jesus' discipleship was:

- Holistic - focussing on the whole person and not purely spiritual or intellectual formation.

- Transformissional - aimed at transforming individuals for the purpose of making disciples.

- Christ centred - at no point were disciples told to make disciples of themselves, but to make disciples of Jesus.
Furthermore, his continued presence was promised in order that he is the central focus of discipleship and not a programme or church.

Post-Christendom era evangelical churches by contrast display person, programme or church service-centred discipleship. There is also a big disconnect between holistic discipleship and pure intellectual or spiritual development. Finally, believers are not equipped to be missional; in fact, individuals are not discipled on how to serve God outside of the church context. Church leaders are asking for resources in the areas of evangelism and discipleship, indicating the need for more focus in this area.

It is encouraging that large and influential evangelical bodies in the United Kingdom are expressing a desire to understand the current discipleship landscape, and priority it should take in church culture, in order to see healthy growth.

\section{Observations from a multidisciplinary perspective}

The research conducted by both the Evangelical Alliance and Elim mention whole life disciples, but an analysis of the reports reveals that evangelical churches aren't doing well with raising whole life disciples. Furthermore, the reports focussed their assessment on spiritual disciplines rather than discipleship in a holistic or whole life context. Therefore, a brief analysis from a multidisciplinary perspective will investigate how much of what happens in church impacts other areas of life.

\section{Census}

The Office for National Statistics created a report on the growth or decline of religions in England and Wales, as revealed in the last census, which was in 2011. This report reveals that although the population grew by 3.7 million in the decade since the last census, Christianity shrunk from $72 \%$ to $59 \%$ of the population. Also, the majority of Christians were older than 60 years. However, the number of people with no religion, particularly aged 20-24 years and $40-44$ years, increased from $15 \%$ to $25 \%$ of the population (ONS 2013:2). Although this article can't investigate all the reasons why this is the case, these initial findings indicate that Christianity is shrinking. This could be down to entering the post-Christendom era where there is less of a Christian worldview in general. Also, it indicates that disciples aren't acting in a missional way to make more disciples.

\section{Family stability}

In what is believed to be the first study of its kind in the United Kingdom, the Marriage Foundation investigated whether religion influenced couples to stay together. The study considered several factors like marital status, education, income and ethnicity as well as religious orientation to determine what caused the most stability in a 
family. What was discovered is that religion and ethnicity had a small influence on the stability of the family. It concluded that Christian families had an advantage over non-religious parents mainly as a result of having a better education and their marital status, as opposed to their Christian faith per se. Although Christian parents are four times more likely to have a degree than Muslim parents, the research didn't explain why that was the case (Benson \& McKay 2016:6-7). What this research reveals, in a striking manner, is that the Christian worldview may encourage marriage and education, both contributing to stability. However, it's not the family's Christian faith influencing how stable they are. This is of concern and a significant area of need for discipleship.

\section{Health}

The Office for National Statistics released a report in 2020 focussed on the influence of religion on health. This report doesn't differentiate between different Christian orientations, but it does indicate that religion in general has an impact on health. For example, those who identified as Christian, Hindu or Jewish were significantly more likely to be satisfied with their health than those who had no religious affiliation. Furthermore, those identified as Sikh, Hindu or Christian reported a greater mean level of mental functioning than those with no religion. Also, religion has an influence on lifestyle choices, like smoking, affecting health (ONS 2020:3). There is much scope for further analysis of the whole impact of religion and Christianity in particular on mental, physical, relational and emotional health. The findings of this report do support the interconnected and holistic nature of the human constitution and that discipleship, as a result, should be holistic in focus.

\section{Summary of observations}

The above summaries are only a scratch to the surface indicating how the holistic nature of people affects discipleship and vice versa. This article doesn't allow the scope to explore topics like neuroscience - how thinking can be transformed through discipleship and the huge consequence transformed thinking will have on discipleship; lifestyle choices like rest, diet and exercise how being healthy in one aspect of your life also benefits every aspect of your life, thus in order to be spiritually healthy physical health is essential; and mental and emotional well-being - how things like awe, fun and laughter counteract the stress hormones in our bodies which cause toxic thoughts, anxiety and long lasting deterioration in health. For too long, discipleship has been exclusively focussed on knowledge, Christian personalities, programmes and spiritual disciplines, and it has neglected how integrated we are as humans. As a result, unhealthy, imbalanced and atomistic disciples have been raised who are not equipped to fulfil the mission of Christ. However, if discipleship emphasis returns to the roots of what Jesus initiated, holistically healthy individuals will be transformed, through a Christ-centred approach, and they will be more effective, longer lasting and better equipped to fulfil his commission.

\section{Conclusion}

There is a paradigm shift required when thinking about discipleship in the post-Christendom era Evangelical Church in the United Kingdom. Insights from a study in the Gospel of Matthew reveal that there is a vivid contrast between the discipleship practiced and commissioned by Jesus and discipleship in the context of church explored in the article. Returning to the holistic and transformissional emphasis of Jesus' discipleship will enable the church to raise healthy Christ followers, who are equipped to fulfil the mission of Christ of making disciples of all nations. Although there are various approaches on how to be missional, including whole life mission, there is not significant emphasis on the importance of disciples being holistically healthy in order to be more effective and enduring in fulfilling their mission. More multidisciplinary research is required to make the link between the intricate holistic nature of the human constitution and how an understanding of that will enable a more transformissional impact of discipleship.

\section{Acknowledgements}

The author (M.F.S.) acknowledges the advice of his doctoral supervisor (D.H.).

\section{Competing interests}

The authors declare that they have no financial or personal relationships that may have inappropriately influenced them in writing this article.

\section{Authors' contributions}

M.F.S. researched and wrote the article under the supervision of D.H. for his PhD thesis.

\section{Ethical considerations}

This article followed all ethical standards for research without direct contact with human or animal subjects.

\section{Funding information}

This research received no specific grant from any funding agency in the public, commercial or not-for-profit sectors.

\section{Data availability}

Data sharing is not applicable to this article as no new data were created or analysed in this study.

\section{Disclaimer}

The views and opinions expressed in this article are those of the authors and do not necessarily reflect the official policy or position of any affiliated agency of the authors. 


\section{References}

Allen, W.C., 2010, A critical and exegetical commentary on the Gospel according to Saint Matthew, Gorgias Press, Piscataway, NJ.

Anderson, J.C., 1994, Matthew's narrative web: Over, and over, and over again, JSOT Press, Sheffield.

Beck, J.R., 2003, 'Self and soul: Exploring the boundary between psychotherapy and spiritual formation', Journal of Psychology and Theology 31(1), 24-36. https://doi. org/10.1177/009164710303100103

Benson, H. \& McKay, S., 2016, Does religion help couples stay together?, viewed 10 February 2021, from https://marriagefoundation.org.uk/research/doesreligion-help-couples-stay-together/.

Berkhof, L., 1958, Systematic theology, Banner of Truth Trust, Edinburgh.

Berkouwer, G.C., 1962, Man: The image of God (studies in dogmatics), Wm. B. Eerdmans Publishing Company, Grand Rapids, MI.

Carter, W., 1997, 'Matthew 4:18-20 and Matthean discipleship: An audience-oriented perspective', Catholic Biblical Quarterly 59(1), 58-75.

Clarke, H., 2003, The Gospel of Matthew and its readers: A historical introduction to the First Gospel, Indiana University Press, Bloomington, IN.

Cooper, J.W., 2000, Body, soul and life everlasting, Eerdmans, Grand Rapids, MI.

Cooper, J.W., 2013, 'Created for everlasting life: Can theistic evolution provide an adequate Christian account of human nature?', Zygon Journal of Religion and Science 48(2), 478-495. https://doi.org/10.1111/zygo.12013

Cortez, M., 2008, Embodied souls, ensouled bodies: An exercise in Christological anthropology and its significance for the mind/body debate, T \& T Clark, London.

Davies, W.D. \& Allison, D.C., 2004, Matthew a shorter commentary, T\&T Clark, New York, NY.

Droge, A.J., 1983, 'Call stories in Greek biography and the Gospels', in K.H. Richard (ed.), Seminar papers, pp. 245-257, CA Scholars, Chico, CA.

Evangelical Alliance United Kingdom (EA UK), 2014, Time for discipleship? 21st century evangelicals: A snapshot of the beliefs and habits of Evangelical Christians in the UK, viewed 01 July 2020, from https://www.eauk.org/church/resources/ snapshot/time-for-discipleship.cfm.

Evangelical Alliance United Kingdom (EA UK), 2020, Discipleship, evangelism and community transformation, viewed 20 January 2021, from https://www.eauk. org/changing-church/autumn-survey/discipleship-evangelism-communitytransformation.

Elim, 2020, Making disciples: Joint research project LICC/ELim, viewed 21 January 2021, from https://www.elim.org.uk/Articles/588293/Research_Discover_what. aspx?redirected $=1$

Erickson, M.J., 1998, Christian theology, 2nd edn., Baker Books, Grand Rapids, MI.

Frede, D. \& Reis, B., 2009, Body and soul in ancient philosophy, De Gruyter, Berlin.

Grudem, W., 1994, Systematic theology: An introduction to biblical doctrine, InterVarsity Press, Leicester.

Hagner, D.A., 1993, Matthew 1-13, Word Biblical Commentary, 33A, Word Books, Publisher, Dallas, TX.
Hagner, D.A., 1995, Matthew 14-28, Word Biblical Commentary, 33B, Word Books, Publisher, Dallas, TX.

Jee, S., 2017, 'A critical evaluation of trichotomism: A response to biblical references for trichotomism', Catalyst Journal of the Institute for Interdisciplinary Studies 15(1), 55-62.

Kaye, B., 2018, The rise and fall of the English Christendom: Theocracy, Christology, order and power, London, Routledge.

Keener, C.S., 2009, Gospel of Matthew: A socio-rhetorical commentary, William B. Eerdmans Publishing Company, Grand Rapids, MI.

Kreider, A., 2016, Patient ferment of the early church: The improbably rise of Christianity in the Roman Empire, Baker Academic, Grand Rapids, MI.

Malina, B.J., 1996, The social world of Jesus and the Gospels, Routledge, London.

Malina, B.J., 2001, The New Testament world: Insights from cultural anthropology, 3rd edn., John Knox Press, Louisville, KY.

Murray, W.S., 2018, Post-Christendom: Church and mission in a strange new world, 2nd edn., Cascade Books, Eugene, OR.

Nolland, J., 2005, The Gospel of Matthew: A commentary on the Greek text, William B. Eerdmans Publishing Company, Grand Rapids, MI.

Office for National Statistics (ONS), 2013, Full story: What does the census tell us about religion in 2011?, viewed 10 February 2021, from https://www.ons.gov.uk/ peoplepopulationandcommunity/culturalidentity/religion/articles/ fullstorywhatdoesthecensustellusaboutreligionin2011/previousReleases.

Office for National Statistics (ONS), 2020, Religion and health in England and Wales: February 2020, viewed 10 February 2021, from https://www.ons.gov.uk/ peoplepopulationandcommunity/culturalidentity/religion/articles/ religionandhealthinenglandandwales/february2020.

Ogne, S. \& Roehl, T., 2019, Transformissional coaching: Empowering leaders in a changing ministry world, Missional Challenge Publishing, s.l.

Osborne, G.R., 2010, Matthew, Zondervan Exegetical Commentary Series on the New Testament, 1, Zondervan, Grand Rapids, MI.

Pedersen, J., 1926, Israel: Its life and culture I-II, Oxford University Press, Oxford.

Robbins, V.K., 1996, Exploring the texture of texts: A guide to socio-rhetorical interpretation, Bloomsbury Academic, London.

Saldarini, A.J., 1994, Matthew's Christian-Jewish community, University of Chicago Press, Chicago, IL.

Sim, D.C., 1998, The Gospel of Matthew and Christian Judaism: The history and socia setting of the Matthean community, T \& T Clark, Edinburgh.

Steenberg, M.C., 2009, Of God and man: Theology as anthropology from Irenaeus to Athanasius, T \& T Clark, London.

Talbert, C.H., 2010, Matthew, Baker Academic, Grand Rapids, MI.

Turner, D.L., 2008, Matthew, Baker Exegetical Commentary on the New Testament, Baker Academic, Grand Rapids, MI.

Willard, D., 2014, The great omission: Reclaiming Jesus's essential teachings on discipleship, HarperCollins, New York, NY.

Zangenberg, J.K. \& Van de Sandt, H. (eds.), 2008, Matthew, James, and Didache: Three related documents in their Jewish and Christian settings, Society of Biblical Literature, Atlanta, GA 